\title{
Cytoplasmic Connexin32 and Self-Renewal of Cancer Stem Cells: Implication in Metastasis
}

\author{
Yasufumi Omori' ${ }^{1}$, Yohei Kawasaki1,2, Qingchang $\mathrm{Li}^{1,3}$, \\ Toshiaki Yoshioka ${ }^{1}$, Yohei Yamamoto ${ }^{1}$ and Katsuhiko Enomoto ${ }^{1}$ \\ ${ }^{1}$ Department of Molecular and Tumour Pathology, Akita University \\ Graduate School of Medicine \\ ${ }^{2}$ Department of Otorhinolaryngology, Akita University Graduate School of Medicine \\ ${ }^{3}$ Department of Pathology, College of Basic Medical Sciences, China Medical University \\ 1,2Japan \\ ${ }^{3}$ China
}

\section{Introduction}

Gap junction is a unique intercellular channel which connects directly the cytoplasm of two neighbouring cells, and allows small $\left(M_{r}<1000\right)$ water-soluble molecules to travel between the cells throughout a tissue, thus serving as a tool of cell-cell communication (Goodenough et al., 1996). In general, gap junction plays crucial roles in tissue and cellular homeostasis and has long been known to suppress carcinogenesis in many tissues (Crespin et al., 2009; Leithe et al., 2006). In the liver, one of the organs where gap junctions are well developed, down-regulation of gap junction between hepatocytes is one of hallmarks for hepatocarcinogenesis (V.A. Krutovskikh et al., 1991). Gap junction is completely disrupted in not only hepatocellular carcinoma but also even precancerous lesions such as GST-P foci (Fitzgerald et al., 1989). A gap junction channel is composed of two hemichannels, which dock with each other to make a complete channel. Hemichannels are provided by each of two neighbouring cells and are called "connexons." The connexon is a hexamer of connexin protein, which forms connexin family consisting of more than 20 members in mammals (Beyer \& Berthoud, 2009; Sohl \& Willecke, 2003). Among them, connexin26 and connexin32 proteins are co-expressed in the hepatocyte (Nicholson et al., 1987; Vinken et al., 2008). During hepatocarcinogenesis, expression of connexin26 protein is abolished. On the other hand, connexin32 protein is reduced in expression but remains expressed not in plasma membrane but in cytoplasm, resulting in total loss of functional gap junction from both hepatocellular carcinoma and its precancerous lesions. More interestingly, the amount of connexin32 protein in cytoplasm often increases in the correspondence with tumour progression and/or the grade of malignancy (Fig. 1) (V. Krutovskikh et al., 1994). Therefore, although connexin32 protein localised in cytoplasm is non-functional as a gap junction component, it may contribute to tumour progression such as invasion and metastasis.

It has long been believed that the tumour is composed of monoclonal cells and thus is a homogenous cell population. According to this idea, every tumour cell should have the ability to develop a new tumour elsewhere and possible heterogeneity should be made only 

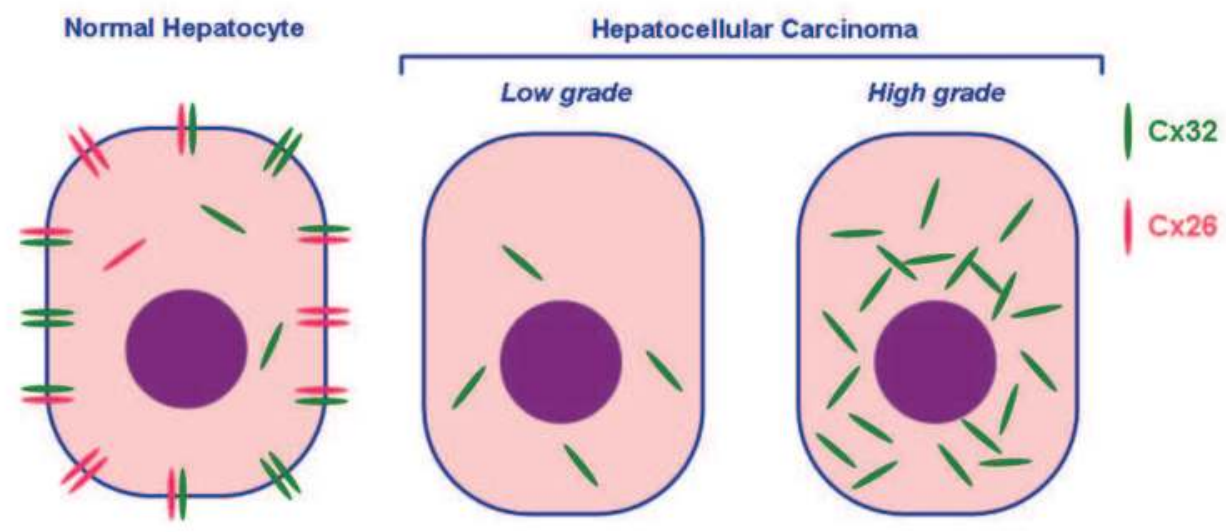

Fig. 1. Expression patterns and subcellular localisation of connexin26 and connexin32 proteins in HCC.

by spontaneous mutations during tumour development and progression. On the other hand, recent intensive studies have revealed that there is cellular hierarchy in a tumour tissue, ranging from stem-like cells to mature tumour cells (Jordan et al., 2006). This latter idea indicates that the tumour is per se a heterogeneous cell population and that only stemlike cells within a tumour tissue have the ability to reconstitute a daughter tumour identical to its mother tumour consisting of heterogeneous cells. These two theories are not necessarily contradictory to each other. Since a certain mutation acquired in a single normal cell is the very first event of carcinogenesis, tumour cells in the same tumour are reasonably monoclonal. It is also true that accumulation of different mutations in individual tumour cells creates heterogeneity in a tumour tissue. The concept on cellular hierarchy in tumour tissues is not brand-new but was already proposed long time ago, i.e., in the first half of the 20th century (Fialkow et al., 1967; Furth \& Kahn, 1937), and has recently been revisited by many scientists with the help of various cutting-edge methods. Today, the stem-like cell is called "cancer stem cell (CSC)" or "tumour-initiating cell (TIC)," depending on individual preferences. Hereafter, CSC is applied for stem-like cell in this chapter. Usually, a tumour tissue contains only a very small number of CSCs and resultantly, almost all cells constituting a tumour mass are non-CSCs. While CSCs isolated from a tumour can develop a tumour when xenografted into immunodeficient animals such as SCID mice, non-CSCs cannot. Therefore practically, CSCs are considered to be a subpopulation having tumorigenicity. Since no absolute marker for CSC has so far been known in any kind of cancers, CSCs are indistinguishable from non-CSCs. All we can do is just to enrich CSCs from the bulk of a tumour by using various markers and a cell sorting system (Klonisch et al., 2008). For example, since CSCs of glioblastoma are contained exclusively in the CD133positive fraction, we can enrich them by isolating the CD133-positive fraction (Singh et al., 2003, 2004). However, since a few non-CSCs are also CD133-positive, no means to purify glioblastoma CSCs have become available yet.

CSCs of hepatocellular carcinoma (HCC) have also been investigated in many laboratories, some of which have succeeded in identifying the CSCs in surgical specimen (Ma et al., 2007; 
Yang et al., 2008a, 2008b; Yin et al., 2007). Surprisingly, presence of CSCs was confirmed in not only HCC in vivo but also HCC-derived cell lines, including human HuH7 cells (Chiba et al., 2006). This finding indicates that there is cellular hierarchy even in immortalised cell lines and that cell lines are not always homogenous cell populations. Thus, employing $\mathrm{HuH7}$ cells, we have investigated roles of cytoplasmic connexin32 protein in metastasis especially in terms of CSC population control.

\section{Cytoplasmic connexin32-mediated control of CSC population and its pro- metastatic roles in $\mathrm{HuH} 7$ cells}

\subsection{Cytoplasmic localisation of connexin protein in cancer}

It is universally accepted that connexin protein is a component of gap junction and thus localised in plasma membrane, where gap junction channels form large clusters called gap junction plaques (Yeager, 2009). When tissue sections are subjected to immunohistochemical staining, these gap junction plaques make impressive punctate signals in a cell-cell contact area (Momiyama et al., 2003). On the other hand, when connexin protein is retained in cytoplasm, their specific signals are often vague and ignored as a kind of background noises (Omori \& Yamasaki, 1998). Finally, a certain number of surgical specimens where no gap junction plaques are formed are likely to be categorised as negative for connexin protein regardless of whether or not it is expressed in cytoplasm.

\begin{tabular}{|c|c|c|}
\hline Histotype of tumour & Connexin & Reference \\
\hline $\begin{array}{l}\text { Hepatocellular carcinoma, } \\
\text { moderately and poorly differentiated }\end{array}$ & $\mathrm{C} \times 32$ and $\mathrm{C} \times 43$ & $\begin{array}{l}\text { V. Krutovskikh et al. (1994) } \\
\text { Oyamada et al. (1990) }\end{array}$ \\
\hline $\begin{array}{l}\text { Adenocarcinoma of the prostate, } \\
\text { poorly differentiated }\end{array}$ & $\mathrm{C} \times 32$ and $\mathrm{C} \times 43$ & Mehta et al. (1999) \\
\hline $\begin{array}{l}\text { Invasive ductal carcinoma (NOS1) of } \\
\text { the breast, grade II and III }\end{array}$ & $\mathrm{C} \times 26$ & Jamieson et al. (1998) \\
\hline $\begin{array}{l}\text { Lymph node metastases of breast } \\
\text { cancer }\end{array}$ & $\mathrm{C} \times 26$ and $\mathrm{C} \times 43$ & Kanczuga-Koda et al. (2006) \\
\hline $\begin{array}{l}\text { Oesophageal squamous cell } \\
\text { carcinoma, poor prognostic group }\end{array}$ & $\mathrm{C} \times 26$ & Inose et al. (2009) \\
\hline
\end{tabular}

${ }^{1}$ Not otherwise specified

Table 1. Cytoplasmic connexin proteins in human cancers

It is well known that gap junctional communication is severely impaired or abolished in almost all tumours during and after the early stage of carcinogenesis (Mesnil et al., 2005). Although downregulation of gap junctional communication results from a decrease in the expression level of connexin mRNA and/or protein in many cases (Leithe et al., 2006), accumulating evidences from careful studies have indicated, as shown in Table 1, that cytoplasmic localisation of connexin protein, probably due to a defect of membrane trafficking, is not rare, and that it is likely one of the mechanisms for the downregulation of gap junctional communication. We estimate that such cytoplasmic localisation of 
connexin could have been observed in human tumours much more frequently than reported. Connexin protein in cytoplasm is non-functional as a gap junction. Does such cytoplasmic connexin play any roles instead of gap junction? Several reports have described suggestive observations on cytoplasmic connexin and tumour progression (Table 1).

V. Krutovskikh et al. (1994) examined 20 surgical samples of human hepatocellular carcinoma for the expression pattern of connexin32 protein and found that poorly differentiated HCC exhibited stronger signals of connexin32 protein in cytoplasm than well differentiated HCC. Mehta et al. (1999) immunostained 20 primary and 20 metastatic lesions of human prostate cancer along with normal counterparts to detect connexin32 and connexin 43 proteins. While both connexin 32 and connexin 43 proteins gave punctate signals in cell-cell contact areas of acinar epithelial cells in both normal and well differentiated adenocarcinoma tissues, both of the connexin proteins were localised in cytoplasm without forming gap junction plaques in poorly differentiated and undifferentiated carcinoma tissues. Jamieson et al. (1998) examined the immunohistochemical expression of connexin26 and connexin43 proteins in 27 cases of invasive ductal carcinoma (not otherwise specified) as well as normal and benign tumour tissues of the human breast and revealed that connexin 26 protein was expressed in cytoplasm in a great majority of the examined cancer samples with grade II or III malignancy while no connexin26 protein was detected in either normal or benign tumour samples. More interestingly, Kanczuga-Koda et al. (2006) clearly showed that the cytoplasmic expression of both connexin26 and connexin 43 proteins was much more frequent in tumours that metastasised to lymph nodes than in the primary lesions of human breast cancers. Most recently, Inose et al. (2009) examined 123 cases of oesophageal squamous cell carcinoma in expression and subcellular localisation of connexin26 protein. While no expression of connexin26 protein was detected anywhere in normal counterparts, connexin 26 protein was expressed in 60 cases $(49 \%)$ and was localised in not plasma membrane but cytoplasm in these cases. Furthermore, they found the direct correlation between connexin 26 expression and the frequency of lymph node metastases, suggesting that cytoplasmic expression of connexin26 protein should be related to cancer progression and poor prognosis rather than carcinogenesis.

Therefore, while disruption of gap junction is a common early event during carcinogenesis, cytoplasmic accumulation of connexin protein seems to accelerate progression of the developed tumours.

\subsection{Accumulation of cytoplasmic connexin32 and enhancement of self-renewal of CSCs in HuH7 HCC cells}

As mentioned above, connexin32 protein translocates from plasma membrane to cytoplasm during hepatocarcinogenesis and its expression level correlates with the grade of malignancy and with the extent of progression in developed HCCs. Since the essential element in a cancer tissue is the CSCs but not matured tumour cells, connexin32 protein in cytoplasm may control progression of HCCs by modulating CSC population. Furthermore, the presence of CSCs in human HuH7 cells had already been proven. We, thus, analysed alteration of CSC population by cytoplasmic connexin32 protein in $\mathrm{HuH} 7$ cells (Kawasaki et al., 2011). 


\subsubsection{Overexpression of connexin32 protein and its subcellular localisation in HCC- derived cells}

Disruption of gap junction in association with translocation of connexin32 protein from plasma membrane to cytoplasm is a common feature of HCCs (V. Krutovskikh et al., 1994; V.A. Krutovskikh et al., 1995). Consistently, we confirmed that this aberrant expression pattern of connexin32 protein was conserved in liver cancer-derived cell lines such as HuH7 (Nakabayashi et al., 1982), Li-7 (Hirohashi et al., 1979), and HepG2 (Aden et al., 1979) cells, the first two of which are derived from HCC and the third one is from hepatoblastoma. These cells are deficient in sorting of connexin32 protein into plasma membrane as is HCC. To examine the effects of cytoplasmic connein32 protein on CSC population, we established a Tet-off-based inducible expression system (Gossen \& Bujard, 1992) of connexin32 in HuH7 and Li-7 cells ( $\mathrm{Li}$ et al., 2007). In this system, expression of exogenous connexin32 mRNA can be blocked by doxycycline. To the contrary, withdrawal of doxycycline from the culture medium induces overexpression of connexin32 mRNA and protein. As shown in Fig. 2, all the clones examined exhibited a significant induction. Especially, the clone 15-1 of HuH7 Tet-off Cx32 cells expressed a 4-time-larger amount of connexin32 protein in the doxycycline-free medium than in the doxycycline-supplemented one.

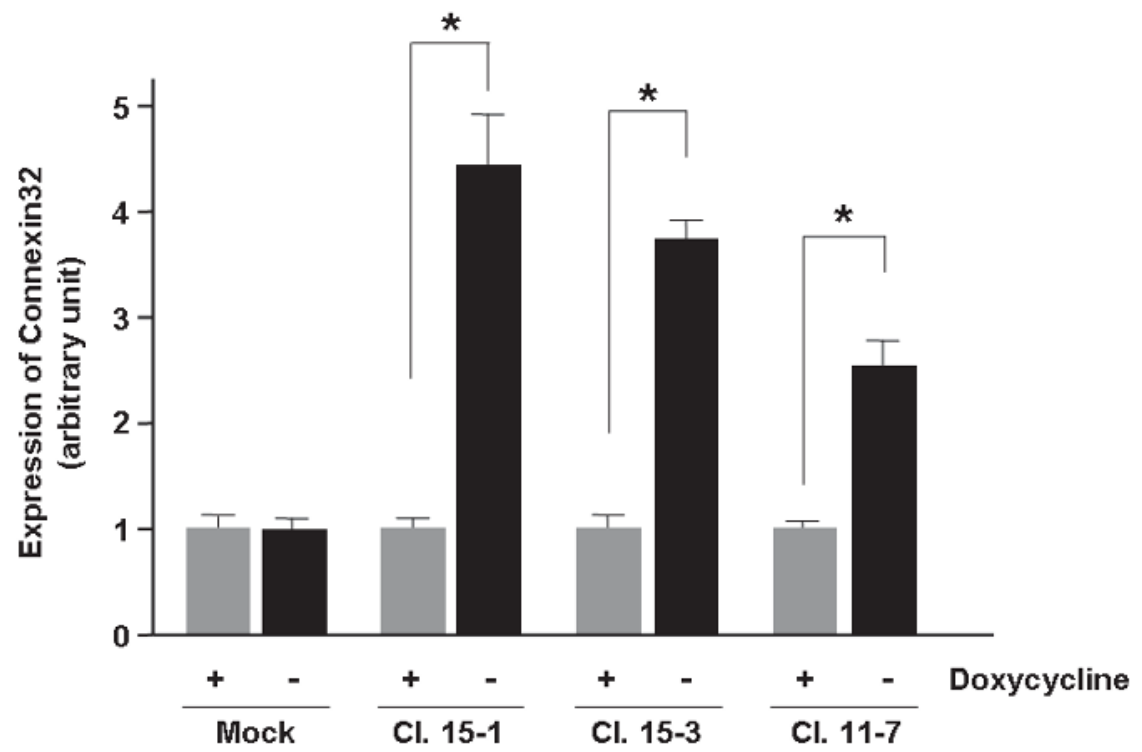

Fig. 2. Expression level of connexin32 protein in HuH7 Tet-off Cx32 and mock cells in the presence or absence of doxycycline. Densitometric analysis of immunoblottings for connexin32 protein. ${ }^{*} p<0.01(\mathrm{n}=3)$

Since either HuH7 or Li-7 cell line has no mutation within the coding region of GJB1 (human connexin32 gene), the exogenous connexin32 protein is identical to the endogenous one and both proteins should behave in the same manner. As expected, connexin32 protein overexpressed in $\mathrm{HuH7}$ cells was co-localised with Golgi-58K protein, as revealed by 
immunofluorescence, in the doxycycline-deprived condition (Fig. 3), indicating that connexin32 protein was localised in Golgi apparatuses in HuH7 cells instead of plasma membrane.

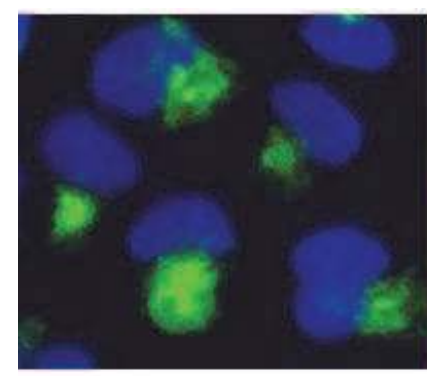

$\mathrm{C} \times 32$

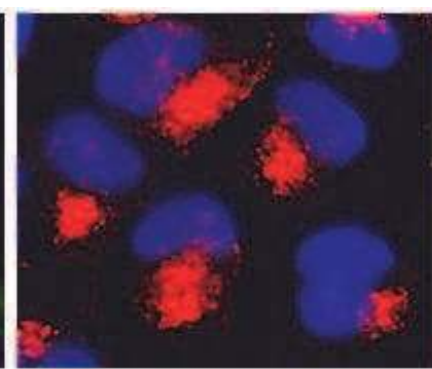

Golgi 58K

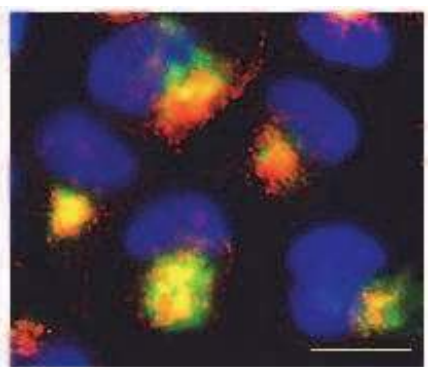

Overlay

Fig. 3. Indirect immunofluorescence of connexin32 protein (left) and Golgi 58K protein (middle) in HuH7 Tet-off Cx32 cells in the absence of doxycycline. Nuclei were stained with diamidine phenylindole dihydrochloride. Note that signals of both connexin32 and Golgi $58 \mathrm{~K}$ proteins are co-localised (right). Scale bar, $20 \mu \mathrm{m}$.

\subsubsection{CSCs of HuH7 cells are contained exclusively in the side population}

Various CSC markers have been proposed in many cancers (Hill \& Perris, 2007; Klonisch et al., 2008). Among them, we chose "side population" because Chiba et al. (2006) had already proven that CSCs of HuH7 cells are efficiently enriched in the side population with little contamination of non-CSCs. Besides side population, we tried another marker CD133, which had also been reported to be expressed in CSCs of HuH7 cells (Ma et al., 2007; Suetsugu et al., 2006). However, CD133-positive cells accounted for $\sim 60 \%$ of the whole population in HuH7 cells (Kawasaki et al., 2011; Ma et al., 2007, 2008). Although the CD133-positive fraction may contain the whole CSC population, the major part of CD133-positive fraction should consist of non-CSCs. So the efficiency of CD133-driven enrichment of CSCs is quite low.

"Side population" is defined as a small subset of cells presenting a highly active efflux of Hoechst 33342 dye. As illustrated in Fig. 4, the side population is thus resistant to the dye and detected by fluorescence-activated cell sorting (FACS). On the other hand, the fraction which is stained with Hoechst 33342 is called "the main population." It is well known that the side population is the fraction into which stem cells in normal tissues are efficiently enriched (Falciatori et al., 2004; Goodell et al., 1996; Shimano et al., 2003). As is the case not only with normal tissues, a number of recent studies on various, otherwise not all, malignant tumours have revealed that the cells from the side population but not from the main population display a series of phenotypes signifying CSC (Grichnik et al., 2006; Hirschmann-Jax et al., 2004; Kondo et al., 2004; Moserle et al., 2008; Szotek et al., 2006; Wang et al., 2007).

To confirm that CSCs of our HuH7 Tet-off Cx32 cells are contained exclusively in the side population, we xenografted the side population and the main population subcutaneously 
into a flank of SCID mice after cell sorting and examined tumorigenicity of the grafts (Table 2). While $1 \times 10^{5}$ cells from the side population developed a tumour at each of six mice examined, $1 \times 10^{5}$ cells from the main population could form no palpable tumours in any mice, indicating that the CSC population resides only in the side population in our HuH7 Tet-off Cx32 and mock cells as well as in parental HuH7 cells. The side populationderived tumours are histologically identical to tumours raised from unsorted HuH7 Tetoff Cx32 cells.

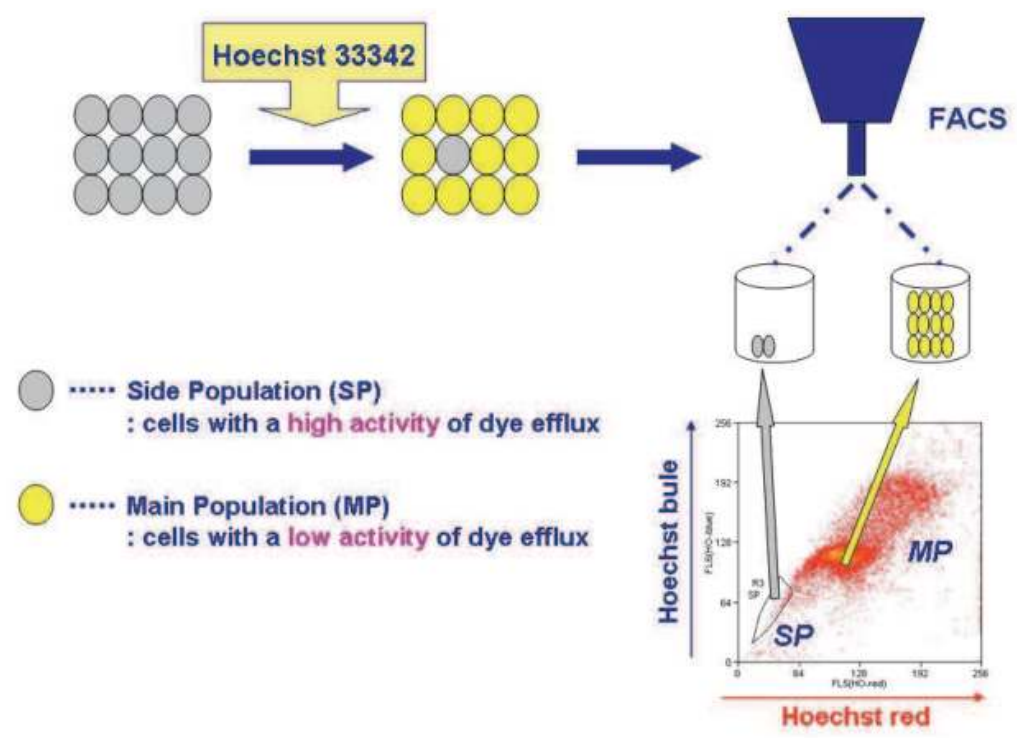

Fig. 4. Schematic diagram on side and main populations.

\begin{tabular}{|c|c|c|c|c|c|c|c|c|c|c|c|c|}
\hline \multirow[b]{3}{*}{ Doxycycline } & \multicolumn{6}{|c|}{ HuH7 Tet-off Cx32 } & \multicolumn{6}{|c|}{ HuH7 Tet-off Mock } \\
\hline & \multicolumn{2}{|c|}{ SP } & \multicolumn{2}{|c|}{ MP } & \multicolumn{2}{|c|}{ US } & \multicolumn{2}{|c|}{$\mathrm{SP}$} & \multicolumn{2}{|c|}{$\mathrm{MP}$} & \multicolumn{2}{|c|}{ US } \\
\hline & + & - & + & - & + & - & + & - & + & - & + & - \\
\hline $\begin{array}{c}\text { No. of mice } \\
\text { bearing tumour }\end{array}$ & 6 & 6 & 0 & 0 & 2 & 3 & 6 & 6 & 0 & 0 & 3 & 3 \\
\hline
\end{tabular}

SP: side population; MP: main population; US: unsorted

Six mice per each group were xenografted with $1 \times 10^{5}$ cells from each fraction.

Table 2. Tumorigenicity of xenografts subcutaneously implanted into SCID mice

\subsubsection{Overexpression of cytoplasmic connexin32 protein expands the side population}

Considering the side population to be a CSC marker of HuH7 cells, we analysed the effects of cytoplasmic connexin32 protein on the CSC population by measuring the size of side population with FACS. In an experiment (Fig. 5), when HuH7 Tet-off Cx32 cells were cultured continuously for 10 days in the presence of $4 \mu \mathrm{g} / \mathrm{ml}$ of doxycycline, the verapamilsensitive side population accounted for $0.27 \%$ of the whole population. In contrast, the side 
population in the cells cultured in a doxycycline-free medium expanded to up to $7.44 \%$ of the whole population. Fig. 5 shows that, in HuH7 Tet-off Cx32 cells, the proportion of the side population to the whole population is approximately 25 times higher in a doxycyclinefree medium than in a doxycycline-supplemented one. Such a doxycycline-dependent alteration of the size of side population is not observed in HuH7 Tet-off mock cells. Therefore, it is concluded that the cell population expressing a higher level of cytoplasmic connexin32 protein contains a larger side population (Kawasaki et al., 2011).

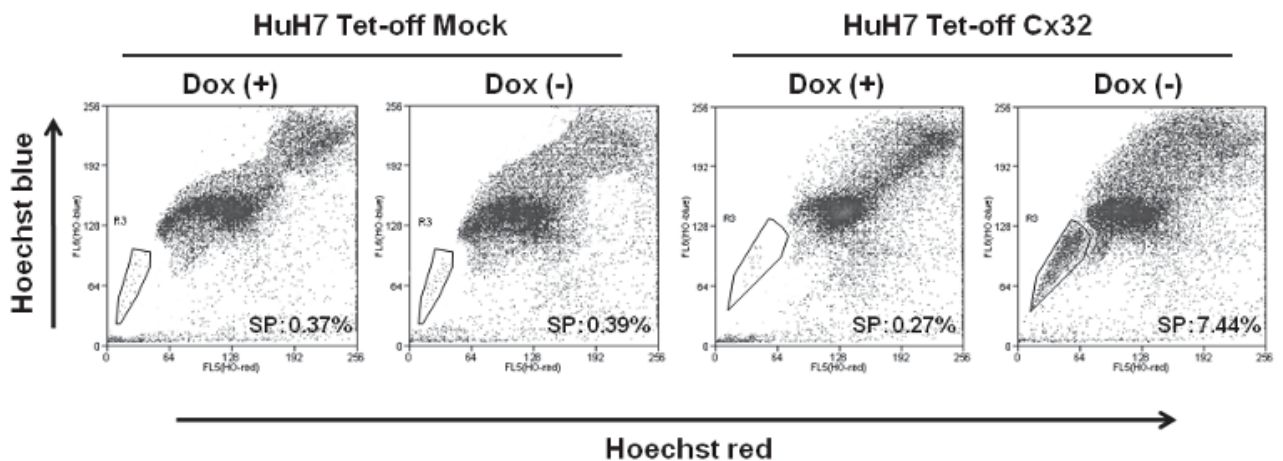

Dox: doxycycline; SP: side population

Fig. 5. FACS analysis of the side population in HuH7 Tet-off Cx32 and mock cells.

\subsubsection{Overexpression of cytoplasmic connexin32 protein enhances self-renewal of CSCs}

Similarly to stem cells in normal tissues, as far as maintained in monolayer culture with a serum-supplemented growth medium, CSCs are obliged to produce non-CSCs, which eventually predominate over CSCs. To avoid maturation of CSCs, they must be cultured in a serum-free medium on a non-attachment dish or in a serum-free semi-solid medium. In this condition, they proliferate as sphere-like cellular aggregates and sustain their undifferentiated state without maturing to non-CSCs, resulting in a pure culture of CSCs (Hermann et al., 2007; Kondo, 2007; Tirino et al., 2008). To define the roles of cytoplasmic connexin32 protein in self-renewal of CSCs, we isolated both the side population and main population separately by FACS and incubated each of them in a serum-free semi-solid medium with or without doxycycline for 20 days. As shown in Fig. 6, the main population had almost no capacity for sphere formation, whereas the side population exhibited an efficient ability to develop numerous large spheres, confirming that the side population of our HuH7 Tet-off Cx32 and the mock cells represented CSCs. As expected, spheres derived from the side population of HuH7 Tet-off Cx32 cells were increased in both number and size in a doxycycline-free medium compared with in a doxycycline-supplemented one (Fig. 6). On the other hand, the side population of HuH7 Tet-off mock cells showed similar capacities for sphere formation regardless of the presence or absence of doxycycline. These results clearly indicate that cytoplasmic accumulation of connexin32 protein enhances selfrenewal of CSCs in HuH7 cells (Kawasaki et al., 2011). 
a

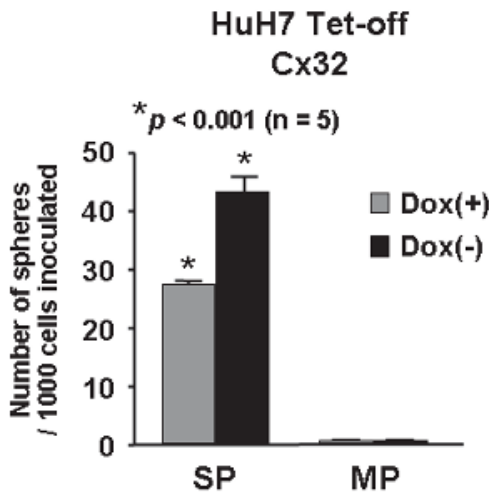

b

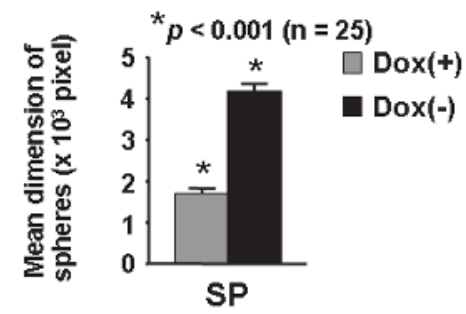

HuH7 Tet-off

Mock
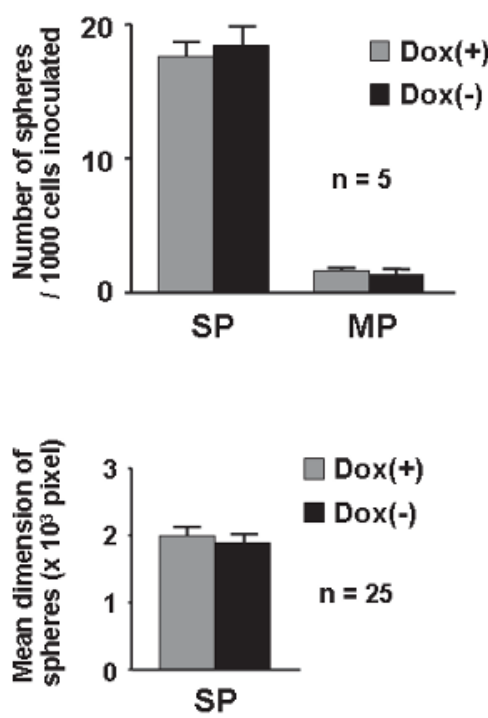

Fig. 6. CSC sphere formation assay in serum-free semisolid medium. The number (a) and the size (b) of developed CSC spheres are presented. SP: side population; MP: main population; Dox: doxycycline

\subsection{Cytoplasmic connexin32-mediated induction of metastasis in $\mathrm{HuH} 7$ cells}

As mentioned earlier, accumulation of different connexin proteins in cytoplasm has often been observed in cancers with high grade malignancy and/or in those of advanced stage (Table 1). Also in HCC, the expression level of cytoplasmic connexin32 protein is elevated as the differentiation state becomes poorer, strongly suggesting that accumulation of connexin32 protein in cytoplasm should contribute to progression of the developed HCC. We, thus, examined the effects of overexpression of cytoplasmic connexin32 protein on migration in vitro and metastasis in vivo (Li et al., 2007).

\subsubsection{Overexpression of cytoplasmic connexin32 protein enhances motility of HuH7 cells}

Upregulation of cell motility is one of the most important steps during tumour metastasis (Thiery, 2002). We examined the effect of the overexpressed cytoplasmic connexin32 on cell motility by performing a serum-stimulated transwell migration assay (Li et al., 2007). Motility of all the examined clones of HuH7 Tet-off Cx32 cells was significantly upregulated in a doxycycline-free medium compared with in a doxycyclinesupplemented one, while doxycycline did not affect motility of HuH7 Tet-off mock cells (Fig. 7). Much interestingly, the Cx32-transfected HeLa cell clone which exhibited a high 
level of gap junctional communication had a much lower motility than mock-transfected HeLa cells. Therefore, it is suggested that connexin32-mediated gap junctional communication should downregulate cell motility, which, to the contrary, cytoplasmic connexin32 protein upregulates. We further investigated whether overexpression of cytoplasmic connexin32 could affect invasiveness of HuH7 Tet-off Cx32 cells by evaluating the ability of HuH7 Tet-off Cx32 cells and mock cells to invade the basement membrane matrix in the presence or absence of doxycycline. When HuH7 Tet-off Cx32 cells were induced to overexpress cytoplasmic connexin32 protein in a doxycycline-free medium, they exhibited a significantly high level of invasiveness (Li et al., 2007).

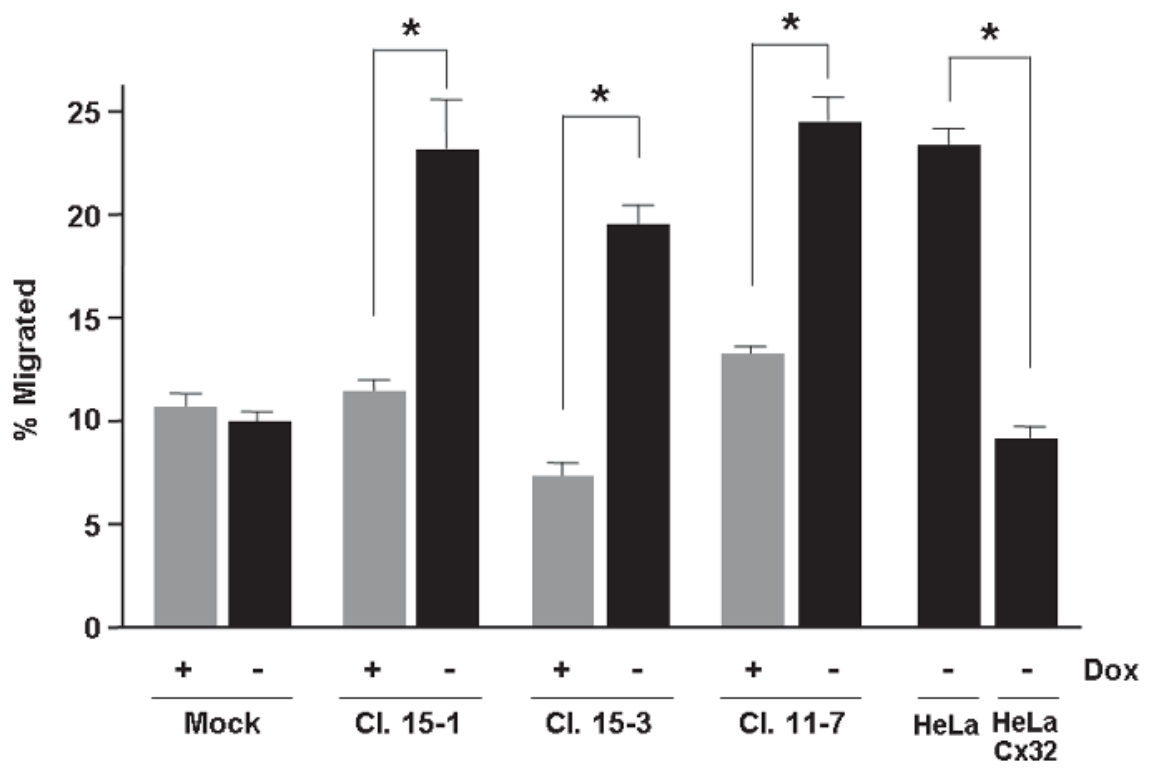

Dox: doxycycline. ${ }^{*} p<0.01(\mathrm{n}=6)$

Fig. 7. Transwell migration assay. Three clones of HuH7 Tet-off Cx32 cells and their mock cells as well as HeLa and Cx32-transfected HeLa cells were examined on the motility.

\subsubsection{Overexpression of cytoplasmic connexin 32 protein induces a metastatic ability in non-metastatic $\mathrm{HuH} 7$ cells}

We examined how HuH7 Tet-off Cx32 cells overexpressing cytoplasmic connexin32 protein behaved in vivo when they were grafted into the liver of immunodeficient SCID mice (Li et al., 2007). Each mouse was given $2 \times 10^{6}$ cells of HuH7 Tet-off Cx32 cells along with mock cells into a subserosal area of the liver and was autopsied 8 weeks after the implantation to observe tumour development and metastases (Fig. 8). For administration of doxycycline, drink water was supplemented with $2 \mathrm{mg} / \mathrm{ml}$ doxycycline throughout the experiment period.

As summarised in Table 3, five out of six mice developed tumours at the implanted sites in each of the doxycycline (+) and the doxycycline (-) groups. The tumour sizes were not 
distinct between the doxycycline (+) and the doxycycline (-) groups. On the other hand, macroscopic metastatic lesions were found in all of the five tumour-bearing mice in the doxycycline (-) group but in none of the mice in the doxycycline $(+)$ group (Table 3$)$. This clearly indicates that the overexpressed cytoplasmic connexin32 protein can give the metastatic ability to HuH7 Tet-off Cx32 cells. Micrometastases and portal vein tumour thrombi were also frequently observed in livers of the doxycycline (-) group given $\mathrm{HuH7}$ Tet-off Cx32 cells.

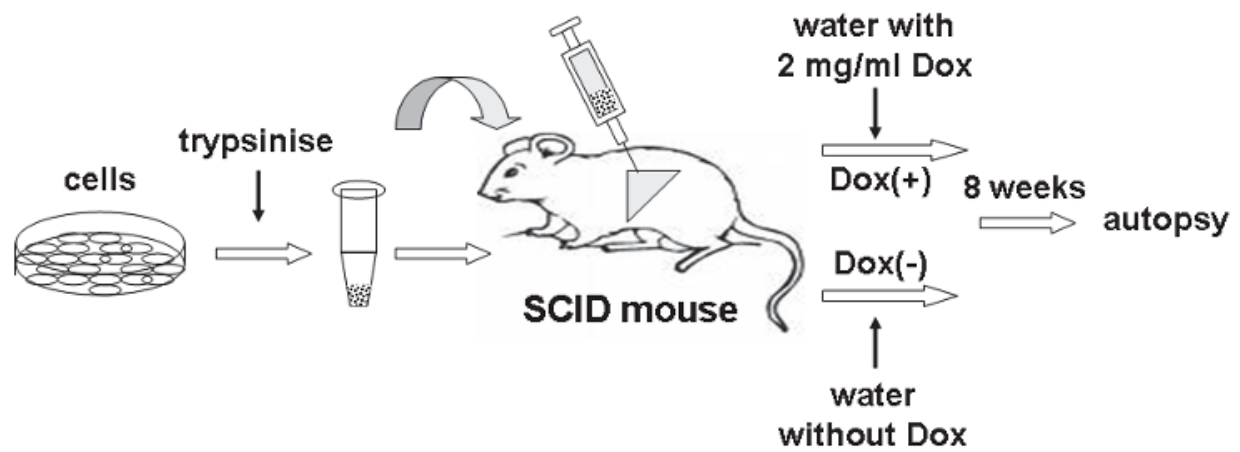

Dox: doxycycline

Fig. 8. Schematic illustration for orthotopic xenograft.

\begin{tabular}{ccccc}
\hline Implanted cells & Doxycycline & $\begin{array}{c}\text { No. of mice } \\
\text { examined }\end{array}$ & $\begin{array}{c}\text { No. of mice } \\
\text { bearing tumour }\end{array}$ & $\begin{array}{c}\text { No. of mice with } \\
\text { metastases }\end{array}$ \\
\hline HuH7 Tet-off Cx32 & + & 6 & 5 & 0 \\
HuH7 Tet-off mock & - & 6 & 5 & 5 \\
& + & 4 & 4 & 0 \\
\hline
\end{tabular}

${ }^{1}$ Li et al., 2007

Table 3. Tumorigenicity and metastasis of orthotopic xenografts in the liver of SCID mice ${ }^{1}$

Taken together, accumulation of connexin32 protein in cytoplasm should be a prometastatic event during progression of HCC.

\section{Conclusive remarks}

In this chapter, we reviewed the literatures describing cytoplasmic connexin proteins in different cancers including HCC and presented our previous studies demonstrating that accumulation of cytoplasmic conneixin32 protein enhanced self-renewal of CSCs in HCCderived cells and resulted in induction of metastasis. What is the impact of the number of CSCs upon metastasis?

In our studies, we hypothesised that expansion of the CSC population should mediate the pro-metastatic function of cytoplasmic connexin32 protein. It is incontestable that cell 
motility and invasiveness are essential factors for metastasis. What these two factors modulate most directly is the length of the latent period between development of a primary tumour and that of its first metastatic focus. On the other hand, the number of CSCs in a tumour should be related closely to the number of metastatic lesions that develop because CSCs are so-called functional seeds that are tumorigenic at a destination site of cell migration while non-CSCs are sterile (Fig. 9) (Jordan et al., 2006). Each metastatic lesion arises from a single CSC but not from non-CSCs. A recent report clearly demonstrated that tumour cells began to circulate in peripheral blood even at the early phase of cancer development, when no risk for metastasis was clinically estimated (Hüsemann et al., 2008; Riethdorf et al., 2008). Taken together, the proportion of CSCs to the whole population in a tumour should be more relevant to the extent of metastasis than the bulk of tumour cells in migration. So it is quite reasonable that cytoplasmic connexin32 protein should enhance the metastatic potential of HCC by expanding its CSC population.

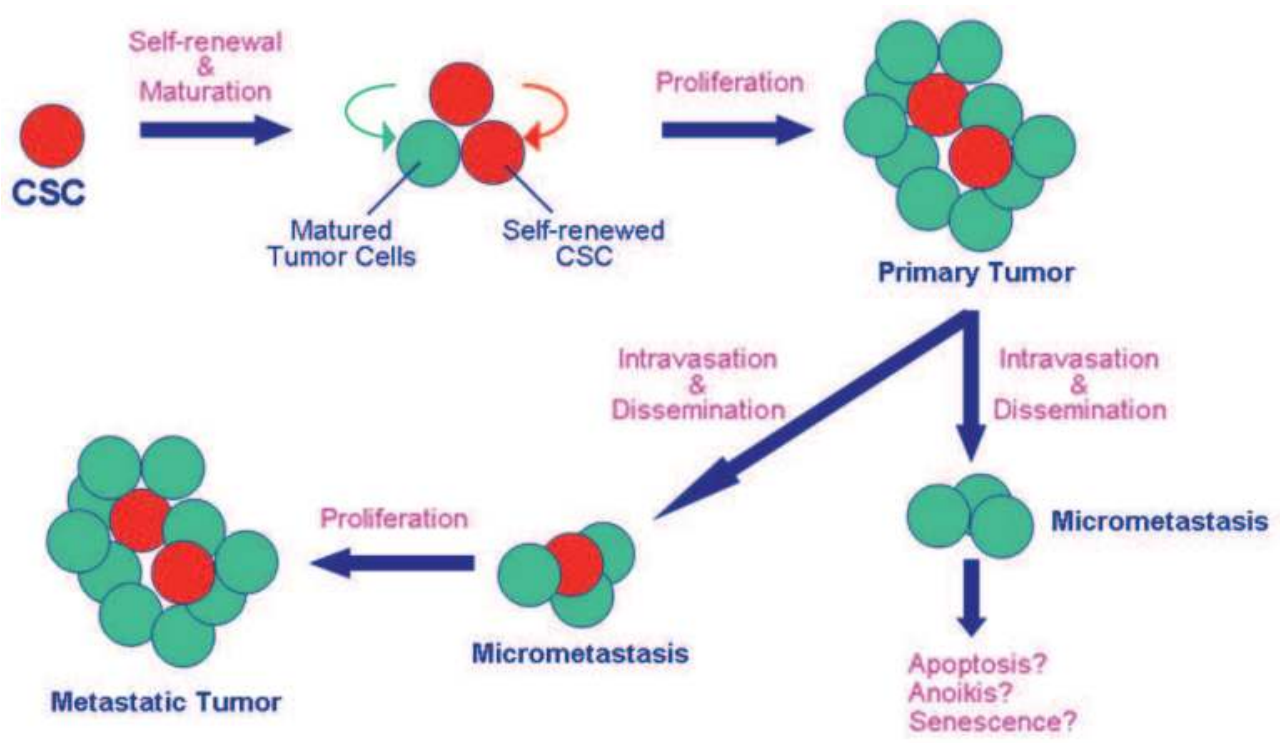

Fig. 9. Each metastatic tumour should be originated from a single cancer stem cell.

For the past five decades, connexin-mediated gap junctional communication has been believed to be one of mechanisms for tumour suppression. This was actually the case. Gap junctional communication efficiently suppressed tumour development in many organs as revealed by both in vitro and in vivo experiments. Today, connexin proteins are, however, beyond gap junction (Goodenough \& Paul, 2003)! A great variety of structures, functions, and behaviours of connexin proteins are known, i.e., hemichannel (Jiang \& $\mathrm{Gu}, 2005$ ), mitochondrial connexin (Boengler et al., 2005), oncogenic connexin (Banerjee et al., 2010; Boengler et al., 2005; Ito et al., 2000), cytoplasmic connexin (Omori et al., 2007), fragmented connexin, and then, gap junction. Therefore, the functions of connexin proteins in cancers are not always suppressive to either cell proliferation or tumour progression (Naus \& Laird, 2010). Complex and diverse functions of connexin proteins still remain to be elucidated in 
this new era. In other words, we will acquire, in near future, novel important knowledge that is presently masked by connexin.

\section{Acknowledgment}

The authors are very grateful to Ms. Reiko Ito and Ms. Yuko Doi for their technical assistance, and to Ms. Eriko Kumagai for her secretarial work. This work was supported in part by a Grant-in-Aid for Scientific Research from the Ministry of Education, Culture, Sports, Science and Technology of Japan (to Y. Omori, Grant No. 21590427). Q. Li was recipient of Japanese Government (MEXT) Scholarship (\#022101).

\section{References}

Aden, D.P., Fogel, A., Plotkin, S., Damjanov, I., \& Knowles, B.B. (1979). Controlled synthesis of HBsAg in a differentiated human liver carcinoma-derived cell line. Nature, Vol.282, pp. 615-616, ISSN 0028-0836

Banerjee, D., Gakhar, G., Madgwick, D., Hurt, A., Takemoto, D., \& Nguyen, T.A. (2010). A novel role of gap junction connexin46 protein to protect breast tumors from hypoxia. International Journal of Cancer, Vol.127, pp. 839-848, ISSN 0020-7136

Beyer, E.C., \& Berthoud, V.M. (2009). The family of connexin genes, IN: Connexins, Harris, A.L. \& Locke, D., pp. 3-26, Humana Press, ISBN 978-1-934115-46-6, New York

Boengler, K., Dodoni, G., Rodriguez-Sinovas, A., Cabestrero, A., Ruiz-Meana, M., Gres, P., Konietzka, I., Lopez-Iglesias, C., Garcia-Dorado, D., Di Lisa, F., Heusch, G., \& Schulz, R. (2005). Connexin 43 in cardiomyocyte mitochondria and its increase by ischemic preconditioning. Cardiovascular Research, Vol.67, pp. 234-244, ISSN 00086363

Chiba, T., Kita, K., Zheng, Y.W., Yokosuka, O., Saisho, H., Iwama, A., Nakauchi, H., \& Taniguchi, H. (2006). Side population purified from hepatocellular carcinoma cells harbors cancer stem cell-like properties. Hepatology, Vol.44, pp. 240-251, ISSN 02709139

Crespin, S., Defamie, N., Cronier, L., \& Mesnil, M. (2009). Connexins and carcinogenesis, IN: Connexins, Harris, A.L. \& Locke, D., pp. 529-542, Humana Press, ISBN 978-1934115-46-6, New York

Falciatori, I., Borsellino, G., Haliassos, N., Boitani, C., Corallini, S., Battistini, L., Bernardi, G., Stefanini, M., \& Vicini, E. (2004). Identification and enrichment of spermatogonial stem cells displaying side-population phenotype in immature mouse testis. FASEB Journal, Vol.18, pp. 376-378, ISSN 0892-6638

Fialkow, P.J., Gartler, S.M., \& Yoshida, A. (1967). Clonal origin of chronic myelocytic leukemia in man. Proceedings of the National Academy of Sciences of the United States of America, Vol.58, pp. 1468-1471, ISSN 0027-8424

Fitzgerald, D.J., Mesnil, M., Oyamada, M., Tsuda, H., Ito, N., \& Yamasaki, H. (1989). Changes in gap junction protein (connexin 32) gene expression during rat liver carcinogenesis. Journal of Cellular Biochemistry, Vol.41, pp. 97-102, ISSN 0730-2312

Furth, J., \& Kahn, M.C. (1937). The transmission of leukemia of mice with a single cell. American Journal of Cancer, Vol.31, pp. 276-282, ISSN 0099-7013 
Goodell, M.A., Brose, K., Paradis, G., Conner, A.S., \& Mulligan, R.C. (1996). Isolation and functional properties of murine hematopoietic stem cells that are replicating in vivo. Journal of Experimental Medicine, Vol.183, pp. 1797-1806, ISSN 0022-1007

Goodenough, D.A., Goliger, J.A., \& Paul, D.L. (1996). Connexins, connexons, and intercellular communication. Annual Review of Biochemistry, Vol.65, pp. 475-502, ISSN 0066-4154

Goodenough, D.A., \& Paul, D.L. (2003). Beyond the gap: functions of unpaired connexon channels. Nature Reviews. Molecular Cell Biology, Vol.4, pp. 285-294, ISSN 1471-0072

Gossen, M., \& Bujard, H. (1992). Tight control of gene expression in mammalian cells by tetracycline-responsive promoters. Proceedings of the National Academy of Sciences of the United States of America, Vol.89, pp. 5547-5551, ISSN 0027-8424

Grichnik, J.M., Burch, J.A., Schulteis, R.D., Shan, S., Liu, J., Darrow, T.L., Vervaert, C.E., \& Seigler, H.F. (2006). Melanoma, a tumor based on a mutant stem cell? Journal of Investigative Dermatology, Vol.126, pp. 142-153, ISSN 0022-202X

Hüsemann, Y., Geigl, J.B., Schubert, F., Musiani, P., Meyer, M., Burghart, E., Forni, G., Eils, R., Fehm, T., Riethmuller, G., \& Klein, C.A. (2008). Systemic spread is an early step in breast cancer. Cancer Cell, Vol.13, pp. 58-68, ISSN 1535-6108

Hermann, P.C., Huber, S.L., Herrler, T., Aicher, A., Ellwart, J.W., Guba, M., Bruns, C.J., \& Heeschen, C. (2007). Distinct populations of cancer stem cells determine tumor growth and metastatic activity in human pancreatic cancer. Cell Stem Cell, Vol.1, pp. 313-323, ISSN 1934-5909

Hill, R.P., \& Perris, R. (2007). "Destemming" cancer stem cells. Journal of National Cancer Institute, Vol.99, pp. 1435-1440, ISSN 0027-8874

Hirohashi, S., Shimosato, Y., Kameya, T., Koide, T., Mukojima, T., Taguchi, Y., \& Kageyama, K. (1979). Production of alpha-fetoprotein and normal serum proteins by xenotransplanted human hepatomas in relation to their growth and morphology. Cancer Research, Vol.39, pp. 1819-1828, ISSN 0008-5472

Hirschmann-Jax, C., Foster, A.E., Wulf, G.G., Nuchtern, J.G., Jax, T.W., Gobel, U., Goodell, M.A., \& Brenner, M.K. (2004). A distinct "side population" of cells with high drug efflux capacity in human tumor cells. Proceedings of the National Academy of Sciences of the United States of America, Vol.101, pp. 14228-14233, ISSN 0027-8424

Inose, T., Kato, H., Kimura, H., Faried, A., Tanaka, N., Sakai, M., Sano, A., Sohda, M., Nakajima, M., Fukai, Y., Miyazaki, T., Masuda, N., Fukuchi, M., \& Kuwano, H. (2009). Correlation between connexin 26 expression and poor prognosis of esophageal squamous cell carcinoma. Annals of Surgical Oncology, Vol.16, pp. 17041710, ISSN 1068-9265

Ito, A., Katoh, F., Kataoka, T.R., Okada, M., Tsubota, N., Asada, H., Yoshikawa, K., Maeda, S., Kitamura, Y., Yamasaki, H., \& Nojima, H. (2000). A role for heterologous gap junctions between melanoma and endothelial cells in metastasis. Journal of Clinical Investigation, Vol.105, pp. 1189-1197, ISSN 0021-9738

Jamieson, S., Going, J.J., D'Arcy, R., \& George, W.D. (1998). Expression of gap junction proteins connexin 26 and connexin 43 in normal human breast and in breast tumours. Journal of Pathology, Vol.184, pp. 37-43, ISSN 0022-4782 
Jiang, J.X., \& Gu, S. (2005). Gap junction- and hemichannel-independent actions of connexins. Biochimica et Biophysica Acta, Vol.1711, pp. 208-214, ISSN 0006-3002

Jordan, C.T., Guzman, M.L., \& Noble, M. (2006). Cancer stem cells. New England Journal of Medicine, Vol.355, pp. 1253-1261, ISSN 0028-4793

Kanczuga-Koda, L., Sulkowski, S., Lenczewski, A., Koda, M., Wincewicz, A., Baltaziak, M., \& Sulkowska, M. (2006). Increased expression of connexins 26 and 43 in lymph node metastases of breast cancer. Journal of Clinical Pathology, Vol.59, pp. 429-433, ISSN 0021-9746

Kawasaki, Y., Omori, Y., Li, Q., Nishikawa, Y., Yoshioka, T., Yoshida, M., Ishikawa, K., \& Enomoto, K. (2011). Cytoplasmic accumulation of connexin32 expands cancer stem cell population in human $\mathrm{HuH7}$ hepatoma cells by enhancing its self-renewal. International Journal of Cancer, Vol.128, pp. 51-62, ISSN 0020-7136

Klonisch, T., Wiechec, E., Hombach-Klonisch, S., Ande, S.R., Wesselborg, S., SchulzeOsthoff, K., \& Los, M. (2008). Cancer stem cell markers in common cancers therapeutic implications. Trends in Molecular Medicine, Vol.14, pp. 450-460, ISSN 1471-4914

Kondo, T., Setoguchi, T., \& Taga, T. (2004). Persistence of a small subpopulation of cancer stem-like cells in the C6 glioma cell line. Proceedings of the National Academy of Sciences of the United States of America, Vol.101, pp. 781-786, ISSN 0027-8424

Kondo, T. (2007). Stem cell-like cancer cells in cancer cell lines. Cancer Biomarkers, Vol.3, pp. 245-250, ISSN 1574-0153

Krutovskikh, V., Mazzoleni, G., Mironov, N., Omori, Y., Aguelon, A.M., Mesnil, M., Berger, F., Partensky, C., \& Yamasaki, H. (1994). Altered homologous and heterologous gap-junctional intercellular communication in primary human liver tumors associated with aberrant protein localization but not gene mutation of connexin 32. International Journal of Cancer, Vol.56, pp. 87-94, ISSN 0020-7136

Krutovskikh, V.A., Oyamada, M., \& Yamasaki, H. (1991). Sequential changes of gapjunctional intercellular communications during multistage rat liver carcinogenesis: direct measurement of communication in vivo. Carcinogenesis, Vol.12, pp. 17011706, ISSN 0143-3334

Krutovskikh, V.A., Mesnil, M., Mazzoleni, G., \& Yamasaki, H. (1995). Inhibition of rat liver gap junction intercellular communication by tumor-promoting agents in vivo. Association with aberrant localization of connexin proteins. Laboratory Investigation, Vol.72, pp. 571-577, ISSN 0023-6837

Leithe, E., Sirnes, S., Omori, Y., \& Rivedal, E. (2006). Downregulation of gap junctions in cancer cells. Critical Reviews in Oncogenesis, Vol.12, pp. 225-256, ISSN 0893-9675

Li, Q., Omori, Y., Nishikawa, Y., Yoshioka, T., Yamamoto, Y., \& Enomoto, K. (2007). Cytoplasmic accumulation of connexin32 protein enhances motility and metastatic ability of human hepatoma cells in vitro and in vivo. International Journal of Cancer, Vol.121, pp. 536-546, ISSN 0020-7136 
Ma, S., Chan, K.W., Hu, L., Lee, T.K., Wo, J.Y., Ng, I.O., Zheng, B.J., \& Guan, X.Y. (2007). Identification and characterization of tumorigenic liver cancer stem/progenitor cells. Gastroenterology, Vol.132, pp. 2542-2556, ISSN 0016-5085

Ma, S., Lee, T.K., Zheng, B.J., Chan, K.W., \& Guan, X.Y. (2008). CD133+ HCC cancer stem cells confer chemoresistance by preferential expression of the Akt/PKB survival pathway. Oncogene, Vol.27, pp. 1749-1758, ISSN 0950-9232

Mehta, P.P., Perez-Stable, C., Nadji, M., Mian, M., Asotra, K., \& Roos, B.A. (1999). Suppression of human prostate cancer cell growth by forced expression of connexin genes. Developmental Genetics, Vol.24, pp. 91-110, ISSN 0192-253X

Mesnil, M., Crespin, S., Avanzo, J.L., \& Zaidan-Dagli, M.L. (2005). Defective gap junctional intercellular communication in the carcinogenic process. Biochimica et Biophysica Acta, Vol.1719, pp. 125-145, ISSN 0006-3002

Momiyama, M., Omori, Y., Ishizaki, Y., Nishikawa, Y., Tokairin, T., Ogawa, J., \& Enomoto, K. (2003). Connexin26-mediated gap junctional communication reverses the malignant phenotype of MCF-7 breast cancer cells. Cancer Science, Vol.94, pp. 501507, ISSN 1347-9032

Moserle, L., Indraccolo, S., Ghisi, M., Frasson, C., Fortunato, E., Canevari, S., Miotti, S., Tosello, V., Zamarchi, R., Corradin, A., Minuzzo, S., Rossi, E., Basso, G., \& Amadori, A. (2008). The side population of ovarian cancer cells is a primary target of IFN-alpha antitumor effects. Cancer Research, Vol.68, pp. 5658-5668, ISSN 00085472

Nakabayashi, H., Taketa, K., Miyano, K., Yamane, T., \& Sato, J. (1982). Growth of human hepatoma cell lines with differentiated functions in chemically defined medium. Cancer Research, Vol.42, pp. 3858-3863, ISSN 0008-5472

Naus, C.C., \& Laird, D.W. (2010). Implications and challenges of connexin connections to cancer. Nature Reviews. Cancer, Vol.10, pp. 435-441, ISSN 1474-175X

Nicholson, B., Dermietzel, R., Teplow, D., Traub, O., Willecke, K., \& Revel, J.P. (1987). Two homologous protein components of hepatic gap junctions. Nature, Vol.329, pp. 732734, ISSN 0028-0836

Omori, Y., \& Yamasaki, H. (1998). Mutated connexin43 proteins inhibit rat glioma cell growth suppression mediated by wild-type connexin 43 in a dominant-negative manner. International Journal of Cancer, Vol.78, pp. 446-453, ISSN 0020-7136

Omori, Y., Li, Q., Nishikawa, Y., Yoshioka, T., Yoshida, M., Nishimura, T., \& Enomoto, K. (2007). Pathological significance of intracytoplasmic connexin proteins: Implication in tumor progression. Journal of Membrane Biology, Vol.218, pp. 73-77, ISSN 00222631

Oyamada, M., Krutovskikh, V.A., Mesnil, M., Partensky, C., Berger, F., \& Yamasaki, H. (1990). Aberrant expression of gap junction gene in primary human hepatocellular carcinomas: increased expression of cardiac-type gap junction gene connexin 43 . Molecular Carcinogenesis, Vol.3, pp. 273-278, ISSN 0899-1987

Riethdorf, S., Wikman, H., \& Pantel, K. (2008). Review: Biological relevance of disseminated tumor cells in cancer patients. International Journal of Cancer, Vol.123, pp. 1991-2006, ISSN 0020-7136 
Shimano, K., Satake, M., Okaya, A., Kitanaka, J., Kitanaka, N., Takemura, M., Sakagami, M., Terada, N., \& Tsujimura, T. (2003). Hepatic oval cells have the side population phenotype defined by expression of ATP-binding cassette transporter ABCG2/BCRP1. American Journal of Pathology, Vol.163, pp. 3-9, ISSN 0002-9440

Singh, S.K., Clarke, I.D., Terasaki, M., Bonn, V.E., Hawkins, C., Squire, J., \& Dirks, P.B. (2003). Identification of a cancer stem cell in human brain tumors. Cancer Research, Vol.63, pp. 5821-5828, ISSN 0008-5472

Singh, S.K., Hawkins, C., Clarke, I.D., Squire, J.A., Bayani, J., Hide, T., Henkelman, R.M., Cusimano, M.D., \& Dirks, P.B. (2004). Identification of human brain tumour initiating cells. Nature, Vol.432, pp. 396-401, ISSN 0028-0836

Sohl, G., \& Willecke, K. (2003). An update on connexin genes and their nomenclature in mouse and man. Cell Communication and Adhesion, Vol.10, pp. 173-180, ISSN 15419061

Suetsugu, A., Nagaki, M., Aoki, H., Motohashi, T., Kunisada, T., \& Moriwaki, H. (2006). Characterization of CD133+ hepatocellular carcinoma cells as cancer stem/progenitor cells. Biochemical and Biophysical Research Communications, Vol.351, pp. 820-824, ISSN 0006-291X

Szotek, P.P., Pieretti-Vanmarcke, R., Masiakos, P.T., Dinulescu, D.M., Connolly, D., Foster, R., Dombkowski, D., Preffer, F., Maclaughlin, D.T., \& Donahoe, P.K. (2006). Ovarian cancer side population defines cells with stem cell-like characteristics and Mullerian Inhibiting Substance responsiveness. Proceedings of the National Academy of Sciences of the United States of America, Vol.103, pp. 11154-11159, ISSN 0027-8424

Thiery, J.P. (2002). Epithelial-mesenchymal transitions in tumour progression. Nature Reviews. Cancer, Vol.2, pp. 442-454, ISSN 1474-175X

Tirino, V., Desiderio, V., d'Aquino, R., De Francesco, F., Pirozzi, G., Graziano, A., Galderisi, U., Cavaliere, C., De Rosa, A., Papaccio, G., \& Giordano, A. (2008). Detection and characterization of CD133+ cancer stem cells in human solid tumours. PLoS One, Vol.3, pp. e3469, ISSN 1932-6203

Vinken, M., Henkens, T., De Rop, E., Fraczek, J., Vanhaecke, T., \& Rogiers, V. (2008). Biology and pathobiology of gap junctional channels in hepatocytes. Hepatology, Vol.47, pp. 1077-1088, ISSN 0270-9139

Wang, J., Guo, L.P., Chen, L.Z., Zeng, Y.X., \& Lu, S.H. (2007). Identification of cancer stem cell-like side population cells in human nasopharyngeal carcinoma cell line. Cancer Research, Vol.67, pp. 3716-3724, ISSN 0008-5472

Yang, Z.F., Ho, D.W., Ng, M.N., Lau, C.K., Yu, W.C., Ngai, P., Chu, P.W., Lam, C.T., Poon, R.T., \& Fan, S.T. (2008a). Significance of CD90+ cancer stem cells in human liver cancer. Cancer Cell, Vol.13, pp. 153-166, ISSN 1535-6108

Yang, Z.F., Ngai, P., Ho, D.W., Yu, W.C., Ng, M.N., Lau, C.K., Li, M.L., Tam, K.H., Lam, C.T., Poon, R.T., \& Fan, S.T. (2008b). Identification of local and circulating cancer stem cells in human liver cancer. Hepatology, Vol.47, pp. 919-928, ISSN 0270-9139 
Yeager, M. (2009). Gap junction channel structure, IN: Connexins, Harris, A.L. \& Locke, D., pp. 27-75, Humana Press, ISBN 978-1-934115-46-6, New York

Yin, S., Li, J., Hu, C., Chen, X., Yao, M., Yan, M., Jiang, G., Ge, C., Xie, H., Wan, D., Yang, S., Zheng, S., \& Gu, J. (2007). CD133 positive hepatocellular carcinoma cells possess high capacity for tumorigenicity. International Journal of Cancer, Vol.120, pp. 14441450, ISSN 0020-7136 


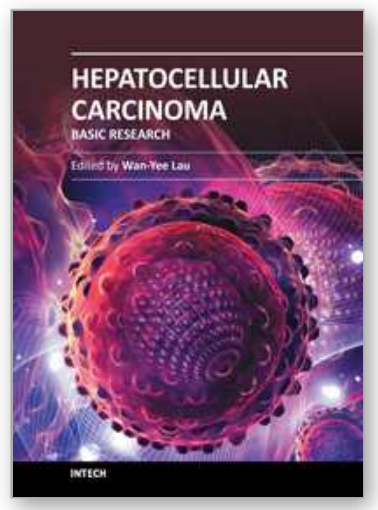

\author{
Hepatocellular Carcinoma - Basic Research \\ Edited by Dr. Joseph W.Y. Lau
}

ISBN 978-953-51-0023-2

Hard cover, 402 pages

Publisher InTech

Published online 10, February, 2012

Published in print edition February, 2012

Hepatocellular Carcinoma represents a leading cause of cancer death and a major health problem in developing countries where hepatitis $B$ infection is prevalent. It has also become increasingly important with the increase in hepatitis $C$ infection in developed countries. Knowledge of hepatocellular carcinoma has progressed rapidly. This book is a compendium of papers written by experts to present the most up-to-date knowledge on hepatocellular carcinoma. This book deals mainly with the basic research aspect of hepatocellular carcinoma. The book is divided into three sections: (I) Biomarkers / Therapeutic Target; (II) Carcinogenesis / Invasion / Metastasis; and (III) Detection / Prevention / Prevalence. There are 18 chapters in this book. This book is an important contribution to the basic research of hepatocellular carcinoma. The intended readers of this book are scientists and clinicians who are interested in research on hepatocellular carcinoma. Epidemiologists, pathologists, hospital administrators and drug manufacturers will also find this book useful.

\title{
How to reference
}

In order to correctly reference this scholarly work, feel free to copy and paste the following:

Yasufumi Omori, Yohei Kawasaki, Qingchang Li, Toshiaki Yoshioka, Yohei Yamamoto and Katsuhiko Enomoto (2012). Cytoplasmic Connexin32 and Self-Renewal of Cancer Stem Cells: Implication in Metastasis, Hepatocellular Carcinoma - Basic Research, Dr. Joseph W.Y. Lau (Ed.), ISBN: 978-953-51-0023-2, InTech, Available from: http://www.intechopen.com/books/hepatocellular-carcinoma-basic-research/cytoplasmicconnexin32-and-self-renewal-of-cancer-stem-cells-implication-in-metastasis

\section{INTECH}

open science | open minds

\section{InTech Europe}

University Campus STeP Ri

Slavka Krautzeka 83/A

51000 Rijeka, Croatia

Phone: +385 (51) 770447

Fax: +385 (51) 686166

www.intechopen.com

\section{InTech China}

Unit 405, Office Block, Hotel Equatorial Shanghai

No.65, Yan An Road (West), Shanghai, 200040, China 中国上海市延安西路65号上海国际贵都大饭店办公楼 405 单元

Phone: +86-21-62489820

Fax: +86-21-62489821 
(C) 2012 The Author(s). Licensee IntechOpen. This is an open access article distributed under the terms of the Creative Commons Attribution 3.0 License, which permits unrestricted use, distribution, and reproduction in any medium, provided the original work is properly cited. 